Global Conferences Series:

Social Sciences, Education and Humanities (GCSSSEH), Volume 6, 2020

International Conference Fakultas Tarbiyah dan Keguruan Universitas Islam Negeri Imam Bonjol Padang (ICFTKUINIBP) 2019

DOI: https://doi.org/10.32698/icftk392

\title{
Students' Perceptions of the Use of Google Classroom to Support Independent Learning
}

\section{Persepsi Mahasiswa terhadap Penggunaan Google Classroom sebagai Penunjang Merdeka Belajar}

\author{
Pipi Deswita $^{\mathrm{a}}$, Remiswal $^{\mathrm{a}}$, Muharmen Suari $^{\mathrm{a}}$ \\ ${ }^{a}$ Universitas Islam Negeri Imam Bonjol, Padang, Indonesia \\ E-mail: pipideswita@uinib.ac.id
}

\begin{abstract}
The purpose of this study was to see students' perceptions of the use of Google Classroom as a support for independent learning. The method used in this research is descriptive method by distributing questionnaires as a data collection technique. The sample in this study were students of Tadris IPA-Physics, Tarbiyah Faculty, Imam Bonjol State Islamic University, Padang. The results of this research data processing are $97.54 \%$ of respondents who filled out the questionnaire have used Google Classroom as a learning support tool, and $92.62 \%$ of them used Andorid as a learning tool. $62.30 \%$ have heard of the term independent learning, and $43,44 \%$ heard the term from a seminar held by the Tarbiyah and Teacher Training Faculty, Imam Bonjol Islamic University, Padang and seminars elsewhere. $66.39 \%$ of Respondents claim that the Google Classroom application helps them to be independent in implementing learning. 58.20\% interested and $49.59 \%$ said the Google Classroom application is good and interesting. 49.18\% of students stated that learning with the Google Classroom application was very supportive, $49.18 \%$ stated that they were not supported because they were constrained by the network.
\end{abstract}

Keywords: Independent learning, google classroom, descriptive

\section{PENDAHULUAN}

Merdeka Belajar adalah Istilah yang baru-baru ini digaungkan oleh Menteri Pendidikan Indonesia Nadiem Makariem. Merdeka Belajar disampaikan dalam pidatonya saat memperingati hari Guru Nasional (HGN) 2019. Program Merdeka Belajar menurut Mendikbud akan menjadi arah pembelajaran ke depan yang fokus pada meningkatkan kualitas sumber daya manusia, Merdeka Belajar menjadi salah satu program untuk menciptakan suasana belajar di sekolah yang menyenangkan, menyenangkan bagi peserta didik maupun bagi para pendidik. Adapun yang melatar belakangi munculnya ide Merdeka Belajar adalah banyaknya keluhan orangtua pada sistem pendidikan nasional yang berlaku saat ini. Salah satunya adalah keluhan soal peserta didik yang dipatok dengan nilai-nilai tertentu (https://mediaindonesia.com/read/detail/278427).

Menurut Nadiem, Esensi dari kemerdekaan berpikir haruslah didahului oleh pendidik sebelum mereka mengajarkan pada peserta didiknya. Nadiem menyebut, dalam kompetensi pendidik di level apa pun, tanpa ada proses penerjemahan dari kompetensi dasar dan kurikulum yang ada, maka tidak akan pernah ada pembelajaran yang terjadi. Pada tahun mendatang, sistem pengajaran juga akan berubah dari yang awalnya bernuansa di dalam kelas menjadi di luar kelas. Nuansa pembelajaran akan lebih nyaman, karena peserta didik dapat berdiskusi lebih dengan pendidik, belajar dengan outing class. Belajar tidak hanya mendengarkan penjelasan pendidik, tetapi lebih membentuk karakter peserta didik yang berani, mandiri, cerdik dalam bergaul, beradab, sopan, dan berkompetensi.

Kemajuan Teknologi dirasakan sangat membantu untuk mewujudkan merdeka belajar dilingkungan Universitas. Salah satu kemajuan tekonologi yang sudah sering digunakan oleh Dosen Tadris IPA-Fisika 
Fakultas Tarbiyah Universitas Islam Negeri Imam Bonjol Padang adalah Google Classrom. Google Clasroom diharapkan dapat menunjang merdeka belajar dalam proses pembelajaran yang berlangsung.

Google Classrom adalah aplikasi pembelajaran online yang memiliki banyak fitur yang praktis, efisien dan terjamin keamanannya, mudah digunakan kapan saja, dimana saja dan dapat diakses secara gratis. Dengan menggunakan Google Classroom diharapkan dapat membantu mahasiswa untuk menemukan atau mengatasi kesulitan pembelajaran, membagikan pelajaran dan membuat tugas tanpa harus hadir di dalam kelas. Dan yang paling penting adalah Google classroom dapat menghemat proses berbagi file antara dosen dan mahasiswa karena dapat terhubung dengan Google Drive dalam pembuatan dan distribusi penugasan, Google Docs, Sheets, Slides untuk penulisan, Gmail untuk komunikasi, dan Google Calendar untuk penjadwalan. mahasiswa dapat diundang untuk bergabung dengan kelas melalui kode pribadi, atau secara otomatis diimpor dari domain sekolah.

Ada beberapa fungsi dan kelebihan Google Classroom dalam pemanfaatannya sebagai Learning Management System (LMS), yaitu : 1) Proses setting pembuatan kelas yang cepat dan nyaman, 2) Hemat dan efisiensi waktu, 3) Mampu meningkatkan kerjasama dan komunikasi, 4) Penyimpanan data yang terpusat, dan 5)Berbagi sumber daya yang efisien, praktis dan cepat

Setelah mengetahui kelebihan dari Google Classroom diatas, membuat aplikasi dari Google yang satu ini menjadi banyak dipilih dalam melangsungkan pembelajaran di sekolah, universitas dan lembaga pendidikan lainnya. Terlebih lagi Google Classroom menjadi primadona bagi pendidik, karena situasi pandemi corona saat ini. Untuk itu penulis tertarik meneliti Persepsi Mahasiswa Terhadap Penggunaan Google Classroom Sebagai Penunjang Merdeka Belajar.

\section{METODE}

Metode yang dipakai dalam penelitian ini adalah metode deskriptif. Menurut Sugiyono (2017) Metode deskriptif adalah Suatu penelitian yang dilakukan untuk mengetahui nilai variabel mandiri, baik satu variabel atau lebih (independen) tanpa membuat perbandingan atau menghubungkan dengan variabel lain. Sedangkan Menurut Hidayat (2010), penelitian deskriptif merupakan metode penelitian yang digunakan untuk menemukan pengetahuan yang seluas-luasnya terhadap objek penelitian pada suatu masa tertentu. Sementara itu Punaji (2010) menyatakan bahwa penelitian deskriptif adalah penelitian yang tujuannya untuk menjelaskan atau mendeskripsikan suatu peristiwa, keadaan, objek apakah orang, atau segala sesuatu yang terkait dengan variabel-variebel yang bisa dijelaskan baik menggunakan angka-angka maupun katakata.

Teknik pengumpulan data yang digunakan pada penelitian ini adalah dengan menyebar kuesioner (angket). Kuesioner digunakan ketika peneliti ingin mengetahui persepsi atau kebiasaan suatu populasi berdasarkanresponden. "Kuesioner merupakan teknik pengumpulan data dengan cara memberi seperangkat pertanyaan atau pernyataan tertulis kepada responden untuk menjawabnya” (Sugiyono, 2017).

Penelitian ini dilaksanakan dengan mengambil sampel dari mahasiswa Tadris IPA-Fisika Fakultas Tarbiyah Universitas Islam Negeri Imam Bonjol Padang. Angket yang disebar diisi oleh 122 orang mahasiswa yang tersebar dari semester 1 sampai 9. Hasil dari penelitian ini selanjutnya diolah berdasarkan isi angket dan dianalisa untuk akhirnya diambil sebuah kesimpulan.

\section{HASIL DAN PEMBAHASAN}

Berdasarkan Angket yang disebarkan kepada mahasiswa Tadris IPA-Fisika melalui google formulir, diperoleh data sebagai berikut:

Berdasarkan tabel 1 terlihat bahwa sebagian besar yang mengisi angket (45,08\%) adalah mahasiswa yang berada pada semester V.Dari tabel 2 dapat diketahui bahwa sebagian besar mahasiswa yang mengisi angket sudah mengetahui istilah merdeka belajar. Sebanyak 62, $30 \%$ mahasiswa Tadris IPA Fisika pernah memdengar, 19,67\% sering mendengar, dan hanya 18,03\% yang baru tahu istilah merdeka belajar ketika mengisi angket.

Pada Tabel 3 25,41 \% mahasiswa Tadris IPA Fisika mendapatkan informasi mengenai istilah merdeka belajar dengan mengikuti Seminar Internasional Fakultas Tarbiyah dan Keguruan UIN IB Padang, 18,03 \% mendapatkan informasi diseminar lain, dan 56,56 \% tidak pernah mengikuti seminar mengenai merdeka belajar.

Dari tabel 4. Diketahui bahwa 36,07 \% sudah merasakan merdeka dalam belajar dengan mengunakan aplikasi google classroom dan 63,93 \% mahasiswa belum merasakan merdeka belajar dengan aplikasi tersebut. Untuk pertanyaan ini responden diminta untuk memberikan alasan terhadap pertanyaan tersebut. 
Mahasiswa yang menyatakan sudah merasakan merdeka belajar menyatakan bahawa dengan mengunakan aplikasi google classroom tersebut mereka merasa bahagia, bebas menerapkan gaya belajar mereka, bebas mencari bahan pelajaran sendiri, merasa tidak terlalu diatur oleh dosen, dapat belajar mandiri, bebas menyatakan pendapat dan aspirasi sehingga dapat meningkatkan keaktifan mereka dalam belajar. Sedangkan mahasiswa yang menjawab belum merasakan merdeka belajar dengan pengunaan aplikasi google classroom karena menurut mereka pengunaan aplikasi ini tidak efektif,tidak terlalu leluasa mengekspresikan apa yang dipelajari, tugas terlalu menumpuk sehingga merasakan tertekan dalam belajar. Selain itu kendala jaringan dan sinyal menebabkan mereka merasa belum merdeka dalam belajar.

Tabel 1. Data Penelitian

\begin{tabular}{lc}
\hline Semester & Jumlah Mahasiswa yang mengisi angket \\
\hline Semester I & 11 \\
Semester III & 25 \\
Semester V & 55 \\
Semester VII & 10 \\
Semester IX & 21 \\
Total & 122 \\
\hline
\end{tabular}

Tabel 2. Informasi mengenai istilah merdeka belajar

\begin{tabular}{llllllll}
\hline & \multicolumn{1}{c}{ Opsi Jawaban } & \multicolumn{4}{c}{ Semester } & \multicolumn{3}{c}{ Total } \\
\cline { 2 - 5 } Belum Pernah Mendengar Sebelumnya, Baru Tahu & & I & III & V & VII & IX & \\
Pernah Mendengar & 1 & 1 & 13 & 2 & 5 & 22 \\
Sering Mendengar & & 10 & 17 & 34 & 4 & 11 & 76 \\
& 0 & 7 & 8 & 4 & 5 & 24 \\
& & 11 & 25 & 55 & 10 & 21 & 122 \\
\hline
\end{tabular}

Tabel 3. informasi pernah mengikuti forum/webinar/sosialisasi/diskusi tentang merdeka belajar

\begin{tabular}{|c|c|c|c|c|c|c|}
\hline \multirow[t]{2}{*}{ Opsi Jawaban } & \multicolumn{5}{|c|}{ Semester } & \multirow{2}{*}{$\begin{array}{l}\text { To } \\
\text { tal }\end{array}$} \\
\hline & I & $\begin{array}{l}\text { II } \\
\text { I }\end{array}$ & $\mathrm{V}$ & $\begin{array}{l}\text { V } \\
\text { II }\end{array}$ & IX & \\
\hline Belum pernah sama sekali & 4 & $\begin{array}{l}1 \\
4\end{array}$ & $\begin{array}{l}3 \\
2\end{array}$ & 6 & 13 & 69 \\
\hline $\begin{array}{l}\text { Pernah Mengikuti Seminar Internasional Fakultas Tarbiyah dan Keguruan } \\
\text { UIN IB Padang }\end{array}$ & 6 & 5 & $\begin{array}{l}1 \\
4\end{array}$ & 2 & 4 & 31 \\
\hline Pernah Mengikuti tapi tidak di Seminar Internasional Fakultas Tarbiyah & 1 & 6 & 9 & 2 & 4 & 22 \\
\hline & $\begin{array}{l}1 \\
1\end{array}$ & $\begin{array}{l}2 \\
5\end{array}$ & $\begin{array}{l}5 \\
5\end{array}$ & $\begin{array}{l}1 \\
0\end{array}$ & 21 & $\begin{array}{l}12 \\
2\end{array}$ \\
\hline
\end{tabular}

Tabel 4. data merasakan merdeka belajar

\begin{tabular}{lllllll}
\hline & Opsi Jawaban & \multicolumn{9}{c}{ Semester } & \multirow{2}{*}{ Total } \\
\cline { 2 - 6 } Belum & I & III & V & VII & IX & \\
Sudah & 9 & 11 & 35 & 8 & 15 & 78 \\
& 2 & 14 & 20 & 2 & 6 & 44 \\
\hline
\end{tabular}

Tabel 5. Alat belajar yang digunakan

\begin{tabular}{lrrrrrrrr}
\hline \multicolumn{1}{c}{ Opsi jawaban } & \multicolumn{9}{c}{ Semester } & \multicolumn{2}{c}{ Total } \\
\cline { 2 - 6 } & I & III & V & VII & IX & \\
Android & 11 & & 22 & 53 & 8 & 19 & 113 \\
Komputer & & 0 & 0 & 0 & 0 & 0 & 0 \\
Laptop & & 0 & 3 & 2 & 2 & 2 & 9 \\
& & 11 & 25 & 55 & 10 & 21 & 122 \\
\hline
\end{tabular}


92,62 \% Mahasiswa Tadris IPA Fisika menggunakan Android sebagai alat untuk menunjang. Sisanya menggunakankomputer dan laptop.

Tabel 6. Data Penggunaan Google Clasroom

\begin{tabular}{lrrrrrrrr}
\hline \multicolumn{1}{c}{ Opsi jawaban } & \multicolumn{9}{c}{ Semester } & \multicolumn{2}{c}{ Total } \\
\cline { 2 - 6 } Pernah & I & III & V & VII & IX & \\
Tidak Pernah & & 11 & & 25 & 55 & 10 & 18 & 119 \\
& & 0 & 0 & 0 & 0 & 3 & 3 \\
\hline
\end{tabular}

97,54 \% Mahasiswa Tadris IPA Fisika sudah menggunakan Aplikasi Google Clasroom sebagai alat untuk proses pembelajarn. Hanya 2,46\% yang belum pernah menggunakan aplikasi Google Clasroom.

Tabel 7. Data Kendala Belajar Menggunakan Google Clasroom

\begin{tabular}{llllllll}
\hline \multicolumn{1}{c}{ Opsi jawaban } & \multicolumn{4}{c}{ semester } & \multicolumn{3}{c}{ Total } \\
\cline { 2 - 6 } & & I & III & V & VII & IX & \\
Aplikasi berat tidak bisa dibuka dengan cepat & 0 & 1 & 3 & 1 & 2 & 7 \\
Kendala jaringan internet & 8 & 21 & 46 & 7 & 18 & 100 \\
Tidak ada kendala yang berarti & 3 & 3 & 6 & 2 & 1 & 15 \\
& & 11 & 25 & 55 & 10 & 21 & 122 \\
\hline
\end{tabular}

Dalam penggunaan Google Classroom 12,29 \% Mahasiswa menyatakan tidak ada kendala yang berarti, 81,97 \% menyatakan terkendala dengan jaringan Internet, dan 5,74 \% menyatakan aplikasi Google Classroom berat untuk dipakai dalam pembelajarn.

Tabel 8. Persepsi mahasiswa terhadap Materi Ajar Menggunakan Google Clasroom

\section{Opsi jawaban}

Membantu mahasiswa belajar mandiri

Sulit dipahami

Tidak membantu sama sekali

\begin{tabular}{|c|c|c|c|c|c|}
\hline \multicolumn{5}{|c|}{ semester } & \multirow[t]{2}{*}{ Total } \\
\hline I & III & $\mathrm{V}$ & VII & IX & \\
\hline 9 & 19 & 32 & 8 & 13 & 81 \\
\hline 2 & 4 & 21 & 2 & 8 & 37 \\
\hline 0 & 2 & 2 & 0 & 0 & 4 \\
\hline 11 & 25 & 55 & 10 & 21 & 122 \\
\hline
\end{tabular}

66,39 \% Mahasiswa mengklaim bahwa belajar dengan menggunakan aplikasi Google Classroom membantu mahasiswa belajar mandiri, 30,33 \% mengklaim bahwa materi ajar yang dibagi dengan GooGle Classroom sulit dipahami, dan hanya 3,28 \% mahasiswa yang mengklaim bahwa Google Classroom tidak membantu sama sekali dalam memahami materi ajar yang menggunakan Google Classroom.

Tabel 9. Minat mahasiswa Mengikuti Pembelajaran Menggunakan Google Clasroom

\begin{tabular}{lllllll}
\hline \multicolumn{1}{c}{ Opsi jawaban } & \multicolumn{9}{c}{ Semester } & \multirow{2}{*}{ Total } \\
\cline { 2 - 5 } kurang minat & I & III & V & VII & IX & \\
minat & 3 & 10 & 22 & 5 & 10 & 50 \\
tidak minat & 8 & 15 & 33 & 4 & 11 & 71 \\
& 0 & 0 & 0 & 1 & 0 & 1 \\
& 11 & 25 & 55 & 10 & 21 & 122 \\
\hline
\end{tabular}

58,20 \% Mahasiswa menyatakan berminat mengikuti pembelajaran dengan menggunakan Google Classroom. 40,98 \% menyatakan kurang berminat, dan 0,82 \% menyatakan tidak berminat sama sekali.

Tabel 10. Apresiasi mahasiswa Terhadap Pembelajaran Menggunakan Google Clasroom opsi jawaban

Bagus dan menarik

Bagus tapi tidak menarik

tidak bagus dan tidak menarik

\begin{tabular}{llllll}
\multicolumn{5}{c}{ semester } & Total \\
\cline { 1 - 3 } I & III & V & VII & IX & \\
8 & 14 & 25 & 3 & 10 & 60 \\
2 & 11 & 27 & 6 & 11 & 57 \\
1 & 0 & 2 & 1 & 0 & 4 \\
11 & 25 & 54 & 10 & 21 & 121 \\
\hline
\end{tabular}


49,59 \% Mahasiswa menyatakan aplikasi Google Classroom bagus dan menarik untuk digunakan dalam proses pembelajaran. 47,11 \% menyatakan Aplikasi Google Classroom Bagus untuk proses pemebalajaran tapi tidak menarik. Dan 3,30\% menyatakan proses pembelajaranyang menggunakan Aplikasi Google Classroom tidak bagus dan tidak menarik.

Tabel 11. Persepsi mahasiswa dengan nilai yang didapatkan setelah belajar dengan menggunakan Google Classroom

\begin{tabular}{|c|c|c|c|c|c|c|c|}
\hline \multirow[t]{2}{*}{ opsi jawaban } & \multicolumn{6}{|c|}{ Semester } & \multirow[t]{2}{*}{ Total } \\
\hline & I & III & $\mathrm{V}$ & VII & IX & $\mathrm{XI}$ & \\
\hline memuaskan & 8 & 18 & 38 & 7 & 14 & 1 & 85 \\
\hline sangat memuaskan & 1 & 4 & 4 & 1 & 1 & 0 & 11 \\
\hline tidak memuaskan & 2 & 3 & 12 & 2 & 6 & 1 & 25 \\
\hline & 11 & 25 & 54 & 10 & 21 & 2 & 121 \\
\hline
\end{tabular}

9,09\% Mahasiswa menyatakan nilai yang didapatkan setelah menmgikuti pembelajaran dengan Aplikasi Google Classroom sangat memuaskan, 70,25 \% menyatakan nilai yang didapatkan memuaskan, dan $20,66 \%$ menyatakan tidak memuaskan.

Tabel 12. Persepsi mahasiswa terhadap kelebihan Google Classroom untuk menunjang merdeka belajar

\begin{tabular}{|c|c|c|c|c|c|c|}
\hline \multirow[t]{2}{*}{ opsi jawaban } & \multicolumn{5}{|c|}{ semester } & \multirow[t]{2}{*}{ Total } \\
\hline & $\mathrm{I}$ & III & $\mathrm{V}$ & VII & & \\
\hline kurang menunjang & 2 & 8 & 30 & 7 & 13 & 60 \\
\hline sangat menunjang & 9 & 16 & 25 & 2 & 8 & 60 \\
\hline tidak menunjang sama sekali & 0 & 1 & 0 & 1 & 0 & 2 \\
\hline & 11 & 25 & 55 & 10 & 21 & 122 \\
\hline
\end{tabular}

49,18 \% Mahasiswa Tadris IPA Fisika menyatakan persepsi mereka terhadap kelebihan Google Classroom sangat menunjang untuk merdeka belajar, 49,18 \% menyatakan kurang menunjang, dan 1,64\% menyatakan tidak menunjang sama sekali. Berikut alasan yang diberikan oleh Responden mengenai persepsi mahasiswa terhadap kelebihan Google Classroom untuk menunjang merdeka belajar: Pada bagian pertanyaan ini responden diminta memberikan alasan terhadap jawaban yang mereka pilih. Sebagian kecil responden menyatakan Google Classroom tidak menunjang sama sekali terhadap merdeka belajar karena aplikasi tersebut tidak menarik, dosen hanya menyampaikan mareri berupa teks saja sehingga menyulitkan mahasiswa memahami apa yang sedang dipajari belum lagi sering terganggu dengan masalah jaringan. Sedangkan mahasiswa yang menyatakan Google Classroom kurang menunjang dalam penerapan merdeka belajar karena sering terkendala jaringan, pembelajaran tidak efektif, mahasiswa belum terlalu bisa belajar mandiri, tugas yang diberikan dosen terlalu banyak dan menumpuk dan membuat mahasiswa merasa tertekan. Selain itu Google Classroom tidak dapat digunakan untuk berdiskusi secara daring karena sering terlambat mendapat notifikasi pesan yang telah dikirim. Mahasiswa yang menyatakan Google Classrom itu sangat menunjang dalam merdeka belajar karena Google Classroom itu mudah untuk digunakan, sangat membantu dalam proses pembelajaran, dapat diakses selama 24 jam, tugas tugas tersusun dengan rapi, tertata, terstruktur, terjadwal sehingga memudahkan mahasiswa dalam mengelola jadwal dengan baik.

\section{SIMPULAN}

Dari hasil dan pembahasan didapatkan bahwa 97,54 \% Responden yang mengisi angket sudah menggunakan Google Classroom sebagai alat penunjang belajar, dan 92,62 \% diantaranya menggunakan Andorid sebagai alat belajar. 62,30 \% pernah mendengar istilah Merdeka Belajar, dan 43,44 \% mendengar istilah tersebut dari mengikuti Seminar yang didakan oleh Fakultas Tarbiyah dan Keguruan Universitas Islam imam Bonjol Padang maupun seminar ditempat lain.

66,39\% Responden mengklaim bahwa aplikasi Google Classroom ini membantu mereka untuk mandiri dalam melaksanakan pembelajaran. 58,20 \% berminat dan 49,9,3\% menyatakan aplikasi Google Classroom bagus dan menarik. 49,188 \% mahasiswa menyatakan bahwa belajar dengan aplikasi Google Classroom sangat menunjang, dan 49,18 \% menyatakan kurang menunjang disebabkan mereka terkendala dengan jaringan. 
Jadi dapat ditarik kesimpulan bahwa persepsi mahasiswa Terhadap Penggunaan Google Classroom Sebagai Penunjang Merdeka Belajar adalah "dapat menunjang”. Jika kendala jaringan dapat diatasi maka penggunaan Google Classroom sebagai penunjang merdeka belajar bisa dipastikan sangat membantu dan menunjang mahasiswa dalam mencapai merdeka belajar.

\section{REFERENSI}

Alimul, Hidayat. 2010. Metode Penelitian Kesehatan Paradigma Kuantitatif. Surabaya: Health Book Publising.

Kahn, Jordan (2014-08-12). "Google Classroom now available to all Apps for Education users, adds collaboration features". 9to5Google (dalam bahasa Inggris). Diakses tanggal 2020-05-09.

Media, Kompas Cyber (2019). "Terobosan Merdeka Belajar Nadiem Makarim, Ubah Sistem Zonasi hingga Hapus UN". KOMPAS.com. (https://mediaindonesia.com/read/detail/278427).

Pidato Menteri Pendidikan dan Kebudayaan (Mendikbud) Nadiem Anwar Makarim. (2019).https://gtk.kemdikbud.go.id/read-news/mengenal-konsep-merdeka-belajar-dan-guru-penggerak Setyosari, Punaji. 2010. Metode Penelitian Penelitian dan Pengembangan. Jakarta: Kencana.

Sugiyono. (2017). Metode Penelitian Kuantitatif, Kualitatif, dan R\&D. Bandung : Alfabeta, CV 